Natural Hazards and Earth System Sciences (2002) 2: 37-49

(C) European Geophysical Society 2002

\title{
Landslide hazard zonation of slopes susceptible to rock falls and topples
}

\author{
M. Parise \\ National Research Council - CERIST, Bari, Italy \\ Received: 1 August 2001 - Revised: 10 December 2001 - Accepted: 19 December 2001
}

\begin{abstract}
A landslide hazard zonation is a division of the land surface into areas, and the relative ranking of these areas according to degrees of actual or potential hazard from landslides on slopes. Zonation from scientific research does not generally imply legal restrictions, but can be useful to those people who are charged with the land management, by providing them with information that is indispensable for planning and regulation purposes. This paper presents a zonation of rock slopes in carbonate mountains on the boundary to the east of the valley of the Sele River (Campania, southern Apennines of Italy). The mountains are severely affected by rock falls and topples, and the related hazard is, therefore, very high; the presence of inhabited areas (the towns of Valva, Colliano and Collianello) and other human infrastructures at the slope foothills make these phenomena extremely dangerous to the anthropogenic environment. The area is highly seismic, as experienced on the occasion of several moderate to strong earthquakes that have hit this sector of the Apennines. According to the zonation proposed here, the ridge of Mount Valva and Mount Marzano is subdivided into four main areas on the basis of the processes which take place in the different sectors of the mountains: the source area, the talus slope, the rock-fall shadow (where scattered outlying boulders are present), and the safe area (outside of the reach of fallen blocks).
\end{abstract}

The four sectors were identified through air-photo interpretation and detailed field surveys, aimed in particular at characterizing and interpreting the main rock mass joint patterns, and their relative orientation with respect to the local slope direction. Geological, morphological and structural analyses permitted one to evaluate and classify those parts of the slope that are more susceptible to detachment of rocks, and to identify the more diffuse types of failure. Due to high seismicity of the study area, particular attention was given to the evaluation of the seismic susceptibility to rock falls, by applying two methods recently proposed in literature. Results from this phase of the study were then integrated by ad-

Correspondence to: M. Parise (cerimp06@area.ba.cnr.it) ditional information from historical research on slope movements occurred previously in the area.

The landslide hazard zonation, shown on large-scale cartography, could be compared to maps depicting the distribution and typology of the anthropogenic activities, and thus constitutes a useful tool for administrators and planners, in order to evaluate the hazards related to slope movements, and the vulnerability of settlements, roads, and other manmade infrastructures.

\section{Introduction}

Rock falls are among the most common type of slope movements in mountain areas worldwide (Porter and Orombelli, 1981; Whalley, 1984; Flageollet and Weber, 1996). They consist of the detachment of a rock from a steep slope, and the consequent descent of material mainly through the air by falling, bouncing, or rolling, which may follow a rock slide or topple. High to very high velocity of the detached material can make this type of landslide extremely dangerous to man and manmade structures, even when involving only small volumes of rocks. Nevertheless, rock falls (and particularly those involving small volumes) have received less attention than many other types of landslides by students and researchers. Regarding destructive mass movements, much focus has, in fact, been addressed concerning catastrophic rockfall-debris avalanches that exhibit a horizontal runout distance, which is dependent on the magnitude of the event, and can result in a travel distance 50-20 times the vertical fall height (Hsü, 1975; Dade and Huppert, 1998). Rock avalanches have certain distinguishing characteristics that are produced by virtue of their size and transport mechanism; to explain their long runout, several hypothesis have been offered so far (e.g. Kent, 1966; Shreve, 1968; Howard, 1973; Goguel, 1978; Melosh, 1979, 1987). The great attention on long-runout rock falls and avalanches was related to the high number of casualties and heavy damage suffered on the occasion of the occurrence of these catastrophic phenomena 


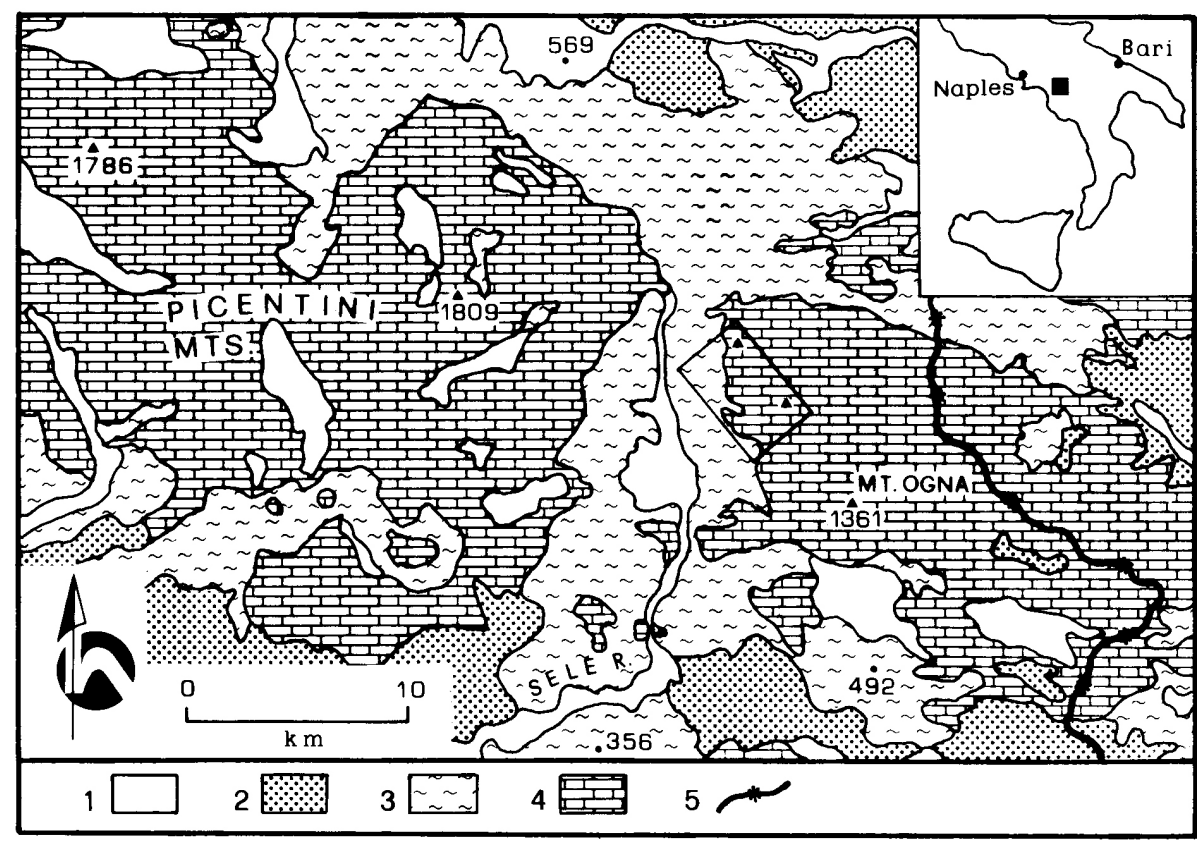

Fig. 1. Location map and geological sketch of the upper valley of the Sele River. Explanation: 1) Alluvial, lacustrine and volcanic deposits (Pleistocene-Holocene); 2) Conglomerate, sands and clays (Pliocene); 3) Argillaceous, marly calcareous, arenaceous turbidites (Trias-Miocene); 4) Carbonate rocks (Trias-Cretaceous); 5) Administrative boundary between Campania (to the west) and Basilicata (to the east). The inset refers to the Mt. Valva-Mt. Marzano ridge, shown as Fig. 2.
(Heim, 1932; Abele, 1972; Voight, 1978; Eisbacher, 1979; Voight et al., 1983; Erismann and Abele, 2001).

Small- to medium-size rock falls, on the other hand, have received much less attention in the scientific literature, despite their greater frequency in many mountain areas of the world. Thus, the related risk for communication routes and inhabited areas located at the mountain foothills has often been underestimated. Rock falls can also induce collateral geological hazards, such as the generation of airblast and abrasive, dense sandy clouds (Morrissey et al., 1999; Wieczorek et al., 2000). Moreover, rock falls are the most abundant type of landslide triggered by earthquakes, as shown by historical worldwide earthquake-induced landslide data compiled by Keefer (1984), and by numerous landslide inventories from post earthquake investigations (e.g. Tazieff, 1961; Hadley, 1964; Harp et al., 1981, 1984; Carrara et al., 1986; Barrows, 1993; Harp and Jibson, 1996; Keefer, 2000; Esposito et al., 2000). A magnitude threshold of 4 is in fact sufficient for triggering falls on the occasion of a seismic event (McCalpin and Nelson, 1996), even though fracturing in the rock mass could locally control the shaking intensity threshold which is required to induce rock falls (Harp and Wilson, 1995); therefore, moderate earthquakes are also able to produce a significant number of these slope movements.

This paper analyzes the susceptibility of slopes to rock falls in the valley of the Sele River (southern Apennines of Italy), aimed at providing an example of zonation of the slopes that could be useful to administrators and planners, in order to create an awareness of the rock-fall hazard and to mitigate the related risk, by reducing its negative effects on the anthropogenic environment. Even though most of the paper will deal with rock falls, toppling failures will also be briefly treated. Topple is defined as a slope movement where "...the forward rotation out of the slope of a mass of rock about a point below the center of gravity of the displaced mass" occurs (Cruden and Varnes, 1996); geological and structural settings which are the most prone to toppling failures are also highly susceptible to rock falls, and topples generally lead to falls of the displaced mass (de Freitas and Watters, 1973; Caine, 1982).

\section{The study area: geology, geomorphology, seismicity}

The mountain areas of Italy are severely affected by rock-fall activity, which causes serious damage throughout the country, from the Alps, to the central and the southern Apennines (Eisbacher and Clague, 1984; Budetta and Santo, 1994).

The study area is located in the Irpinia region, within a very complex sector of the southern Italian Apennine thrust belt. The Sele River runs in a N-S valley (Fig. 1) carved in flyschoid deposits, and made of a complex alternance of different lithologies (clays, marls, sandstones, limestones) with an overall prevalence of clay-like materials; the valley is bounded on both sides by carbonate massifs, namely the Picentini Mountains to the west, and the Mount Valva - Mount Marzano - Mount Ogna ridge to the east (Figs. 1 and 2). Apennine tectonics, which started in the middle to late Miocene and continued throughout the Plio-Pleistocene, caused large-scale dislocations of the Mesozoic-Tertiary carbonates and the overlying Messinian and Pliocene terrigeneous marine deposits (Ippolito et al., 1975; Brancaccio et al., 1991; Cinque et al., 1993). The present morphostructural setting of the valley and nearby areas has been mostly shaped during the last Pliocene-Quaternary events (Amato et al., 1992). 


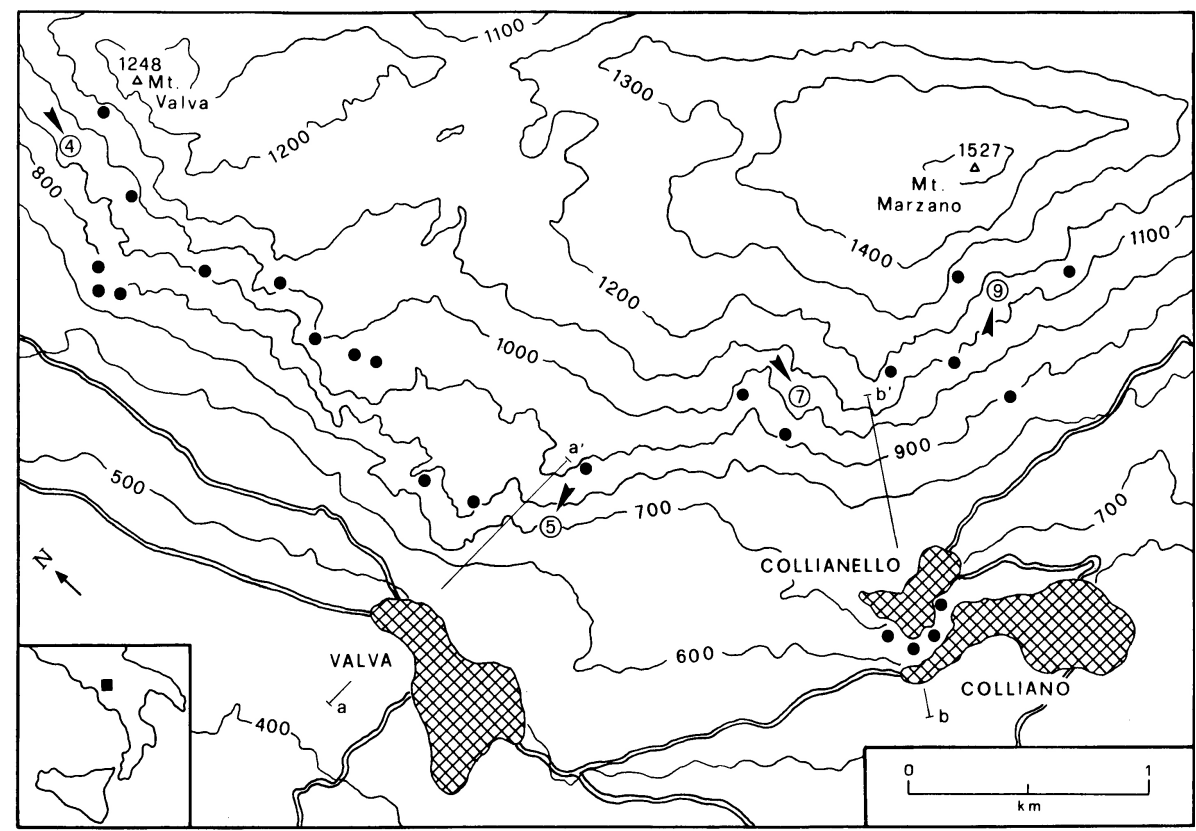

Fig. 2. Topography of the study area Black dots mark the rock falls identified through historical investigation. Circled numbers and open arrows indicate location and view of photo sites. Inhabited areas and main communication routes are also shown

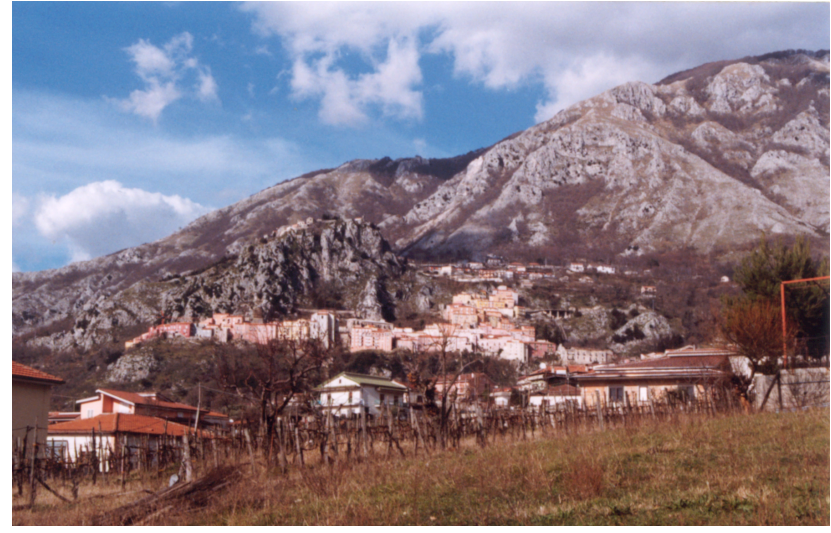

Fig. 3. View of the Mt. Valva-Mt. Marzano ridge. The town of Colliano is at the center of the photo, while the houses of Collianello are visible at the top of the rocky spur above Colliano.

The mountain ridge formed by the peaks of Mount Valva (1248 m a.s.l.) and Mount Marzano (1527 $\mathrm{m}$ a.s.l.), and the towns of Valva, Colliano and Collianello, which are located at the immediate mountain foothills (Figs. 2 and 3), are the objects of this study: the ridge rises at the eastern border of the valley, at the administrative boundary between Campania and Basilicata. Elongated in a NW-SE direction, it is formed by a Trias-Cretaceous carbonate succession made of limestones and, subordinately, of dolomitic limestones and dolomites, and is limited by normal faulting on its western side. Rock mass is heavily fractured. Slope height is on the order of several hundred meters; the outer portions of the carbonate massifs are characterized by steeply inclined to vertical walls that border the mountains toward the valley of the Sele River.

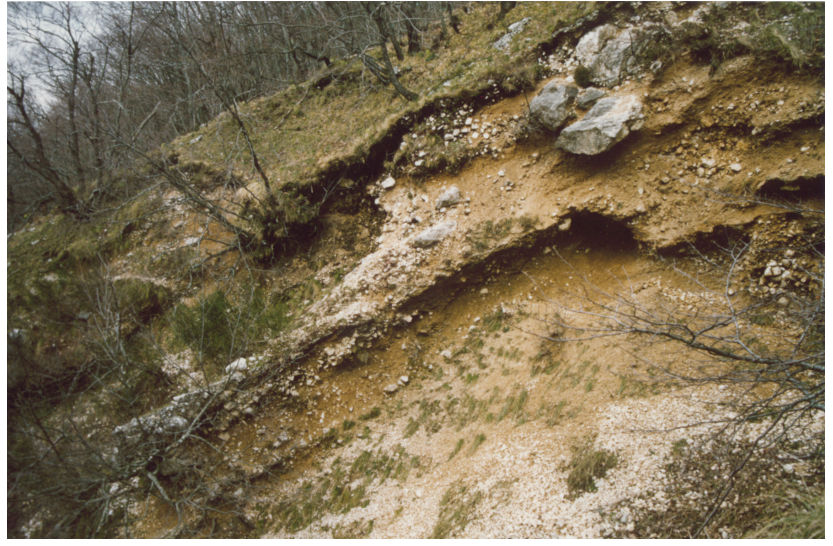

Fig. 4. Cemented limestone breccias on the western slope of Mt. Valva. The largest boulder at the upper right corner is $1.2 \mathrm{~m}$ long. Breccias are inclined following the average slope gradient, that is $35^{\circ}$ in this sector.

In the lower valley, on the other hand, structurally complex terrains crop out, with prevailing clay-like lithofacies, which determines an overall high susceptibility of the slopes to landsliding (Parise, 2001). Scree accumulations connect the steeply inclined to vertical carbonate rock walls to the flysch successions in the valley. They consist of fragments of rocks ranging extremely in size, which form high-gradient slopes with a natural sorting by size, showing the coarsest boulders toward the base of the slope, a common feature on the talus slope in mountain areas (Kotarba and Stromquist, 1984). The deposits on the talus slope have an indurated crust made of well cemented carbonate breccias (Fig. 4). Slopes are scarcely vegetated, and in wide areas vegetation is absent or consists only of shrubs. The upper valley of the Sele 
Table 1. List of great earthquakes felt in the study area (data from Boschi et al., 2000). $I_{0}$ is epicentral intensity, $I_{L}$ local intensity (localities between brackets), $M$ magnitude

\begin{tabular}{llclc}
\hline Date & Epicentral area & $I_{0}$ & \multicolumn{1}{c}{$I_{L}$} & $M$ \\
\hline 8 September 1694 & Irpinia - Basilicata & X-XI & VIII (Valva and Colliano) & 6.8 \\
9 April 1853 & Irpinia & IX & VI (Colliano), IV-V (Valva) & 5.9 \\
16 December 1857 & Basilicata & XI & VI (Valva) & 6.9 \\
7 June 1910 & Irpinia - Basilicata & VIII & VI (Colliano) & 5.8 \\
23 November 1980 & Irpinia - Basilicata & X & VIII (Colliano and Valva) & 6.8 \\
\hline
\end{tabular}

River is an active seismogenetic zone: Table 1 lists the main earthquakes felt in the study area, and also provides the local intensity at Valva and Colliano for each event. Landsliding events (including rock falls at Valva and Colliano) have been recorded on the occasion of the 1694 and 1980 earthquakes. No historic documents have been found about the occurrence of rock falls during the other listed earthquakes; however, this possibility cannot be excluded.

\section{Rock falls and topples}

\subsection{Rock slope instability in the valley of the Sele River}

Rock falls have peculiar features which distinguish them from the other types of slope movements: a rock-fall deposit is rarely in contact with, or resting at a short distance from its source area; more commonly, it is able to travel, also for great distances, and stop after quite a long path. Thus, distribution and sorting of rock-fall deposits reflect these features, yet they are controlled by other factors, such as topography, morphology, and the presence and type of vegetation on the slopes (Broili, 1977; Moriwaki, 1987).

As previously stated, the valley of the Sele River is highly prone to landsliding due to its geological and structural characteristics. In spite of slope movements being the main geomorphic process shaping the landscape in the area, landslides were only briefly mentioned in the geological literature of this sector of the southern Apennines, and only one paper (de Riso, 1967) specifically dealt with them before the 1980 earthquake: in this paper, the author highlights mostly the slope movements involving the clay-like materials by subdividing the area into four main sectors. Rock falls deserve only a brief citation, and the overall degree of hazard from this type of slope movement is considered to be low, when compared to that of the other sectors, characterized mostly by flow-type landslides (de Riso, 1967).

In the aftermath of the 1980 seismic event, many studies have been dedicated to slope movements triggered by the earthquake, from analysis at a regional scale to specific-site studies dealing with single landslides. In particular, the maps accompanying the works by Budetta (1983) and by Carrara et al. (1986) show a number of rock-fall source areas on the slopes above the towns of Valva, Colliano and Collianello.

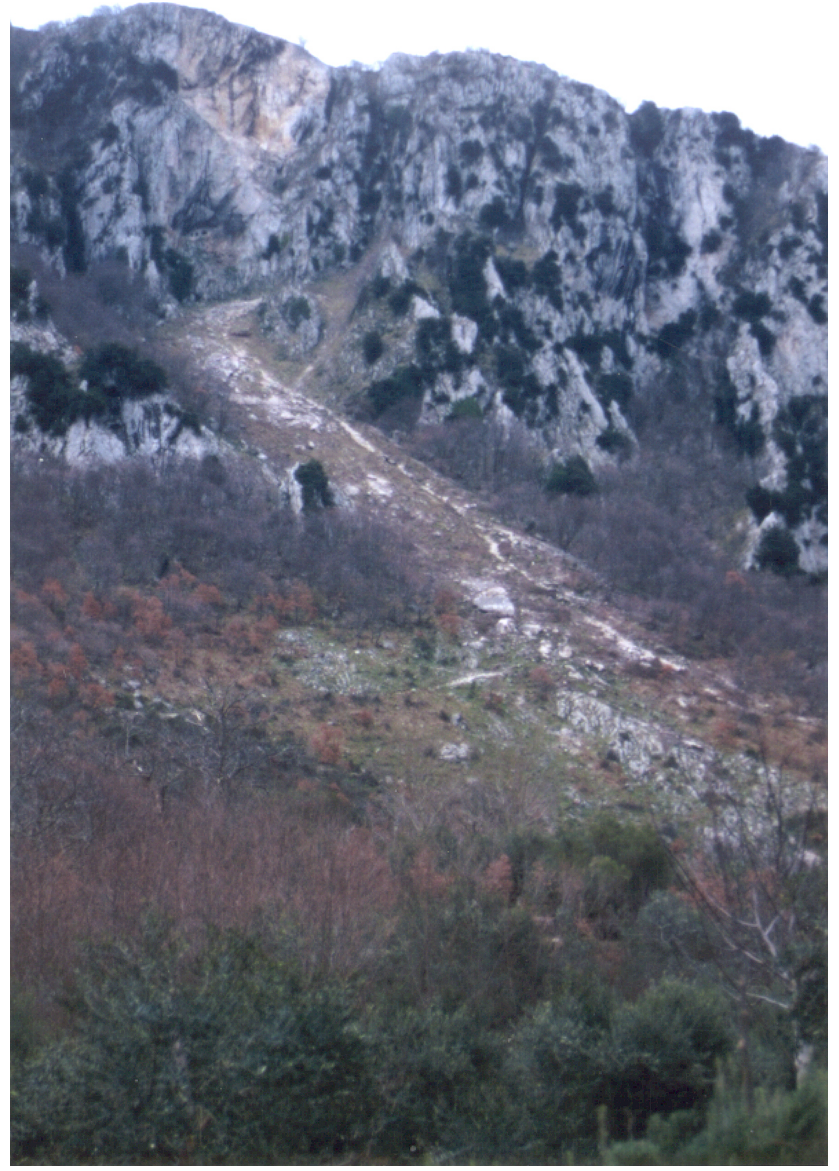

Fig. 5. Rock-fall source area in the mountain above the town of Valva. Note the high gradient of the talus slope, and the freshness along the rock-fall path, the latter testifying to recent slope movement activity.

Research carried out in the last few years permitted one to collect data on the location and time of occurrence for more than 20 rock falls in the study area (Fig. 2; Parise, 1999); this number appears low when considering information obtained from local inhabitants, who report frequent, although generally small in size, rock falls every winter and spring season. The numerous fresh rock scars, as well as the accumulations of rock blocks in chutes fed from the rock walls, also attest to the continuing occurrence of rock falls and topples (Fig. 5). Many rock fragments and blocks of different size may rest 

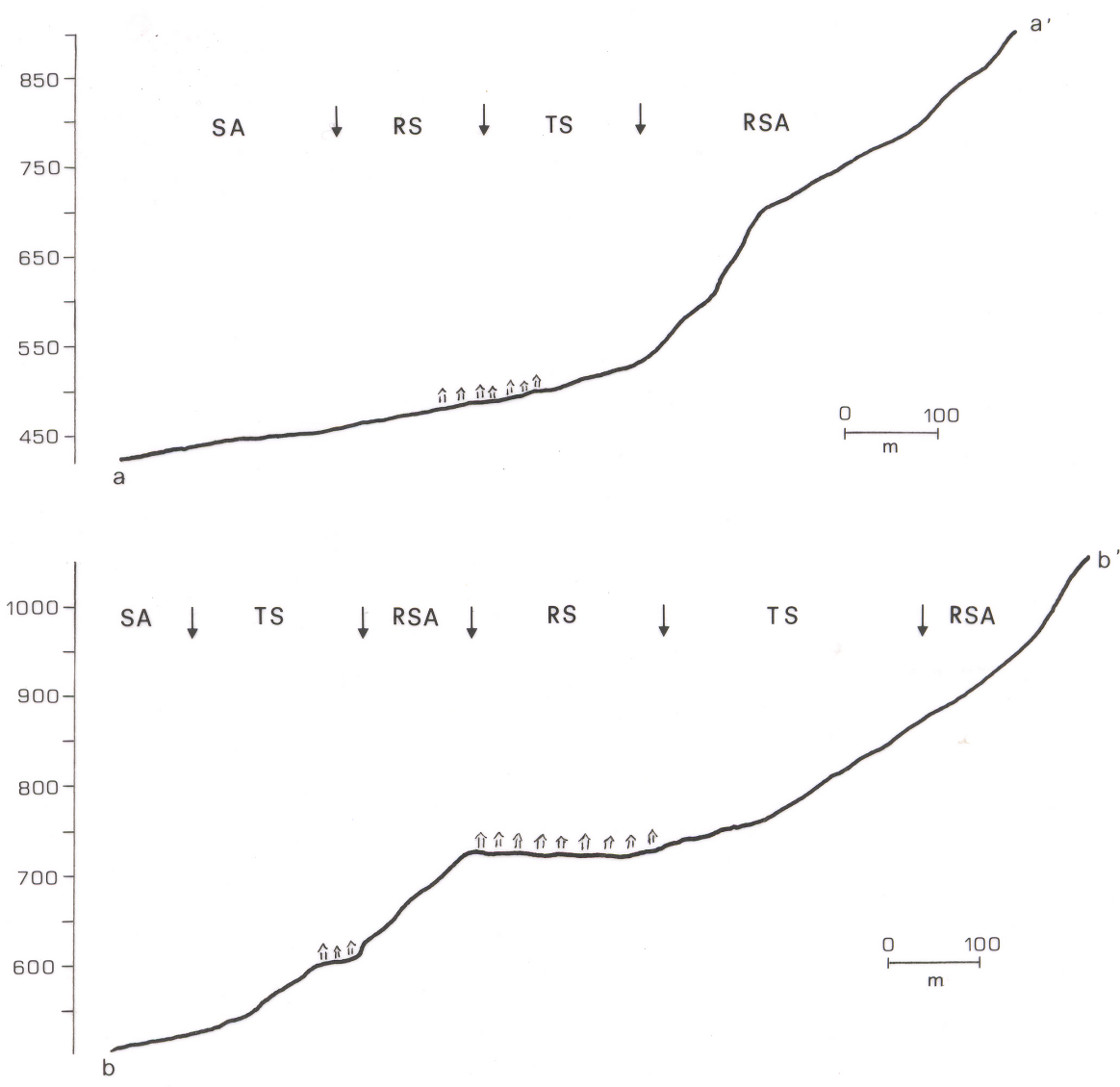

Fig. 6. Topographic profiles at the western slopes of Mt. Valva and Mt. Marzano (for location see Fig. 2). Explanation: RSA = rock-fall source area; $\mathrm{TS}=$ talus slope; $\mathrm{RS}=$ rock-fall shadow; $\mathrm{SA}=$ safe area. after disintegration, due to the impact following the first fall on ledges eventually present on the slopes; from there, they can again be subject to a fall, or be involved in other falls from material movement from the above cliff, thus being a nuisance to roads found below. Even small rock falls can, in fact, be a real danger when buildings and roads are located at the mountain foothills. Based on these considerations, some authors have proposed a distinction between primary and secondary falls (Matznetter, 1956; Luckman, 1976): primary falls are those just released from the rock face, while secondary falls are those which result from the transport of previously released material that has been resting on ledges. Such distinction, which is not always an easy task, can be performed through detailed observation of fresh source areas on the rock cliff, and of weathered surfaces on the fallen material, or of their lichen cover. Local morphology of the Mt. Valva - Mt. Marzano ridge is characterized at very few sites by changes in the slope gradient below the rock cliff: more commonly, the talus slope shows high to very high gradients (Fig. 6) which make it less likely to stop fallen blocks, and for secondary falls to occur. Thus, nearly all of the rock falls in the study area can be considered as primary.

\subsection{Structural survey}

One of the most obvious problems in investigating a rock cliff is accessibility. Practical problems of measurements had to be faced during the survey at Mt. Valva and Mt. Marzano: due to verticality of many rock walls, and to the difficulty in the accessibility of some sites, speleological techniques of caving explorations have been used. This permitted one to collect data on the source areas of all the known rock falls (and particularly those triggered by the 1980 earthquake), and to characterize their areas of detachment and type of failures. Macroscopic and mesoscopic structural analysis have been conducted by means of surveying the main joint sets and the prevailing directions of kinematic indicators. In order to diminish as much as possible any inaccurate representation of the true joint pattern, which could derive from measures performed only at the more accessible sites (Terzaghi, 1965; La Pointe and Hudson, 1985; Dershowitz and Einstein, 1988), a systematic survey through equally-spaced scanlines covering the ridge along its overall length and height was performed; this was integrated by measurements taken at the known rock-fall source areas. Eventually, more than sixty measurement stations were surveyed, with an average spacing between stations of about $50 \mathrm{~m}$. At those sites where significant changes in the fracturing of the rock mass was observed, additional stations were established.

The survey was focused on the identification and interpretation of the most important features needed for a complete characterization of the rock mass (Geological Society Engineering Group Working Party, 1977; Hoek and Bray, 1981; 
Hudson and Priest, 1983): type of discontinuity, orientation, spacing, aperture, infilling, persistence, etc.; particular attention was also paid to karst features and weathering. The effect of weathering can be very important in the rock-fall predisposition of slopes: some authors state that it is possible to view rock fall as a whole as a form of weathering process. In other words, it can be considered as the expression of weathering at work in the outermost few metres of rock faces (Whalley, 1984). In the case of limestone terrain, effects of weathering can be very severe, due to a combination of physical alteration and limestone solution (Dearman, 1981; Fookes and Hawkins, 1988). The latter, in particular, may play a significant role in enlarging joints and fractures, and in favouring detachment of rocks along the outer ridges (Kowalski, 1991).

Bedding in limestones and dolomitic limestones in the study area is identifiable only at few sites, due to massive aspects of carbonate rocks; in addition, measured beddings are not consistent, as a consequence of faulting that produced local changes in the strata attitude. It has to be noted that stratification does not appear to control the failures in the rock mass, while much more important is the structural control exerted by other discontinuities. The most significant rock discontinuities identified and recorded in the field study were, in fact, faults and joints, whose main directions are elongated in NW-SE trending (subordinate, but frequent, directions are NE-SW, and NNW-SSE). These trends reflect the orientation of the entire ridge, bounded on its western and southern slopes by normal faults. Regarding slickensided fault surfaces, it has to be stressed that subvertical or high-angle faults are much more diffuse, and have a fresher appearance, than fault surfaces with oblique slickensides; they cut other low-angle faults with compressional character. Thus, normal high-angle faults related to extensional tectonics, which began in the Pliocene-Pleistocene time, and are still active at the present time, are the most recent tectonic features in the area; this is in agreement with the results of a structural survey performed at Mount Marzano and nearby carbonate massifs of the southern Apennines of Italy by Coppola and Pescatore (1989).

Joints were observed in all of examined rock outcrops; in detail, at each measurement station, at least two families of joints were identified. They generally define blocks whose largest dimensions ranges from less than $15 \mathrm{~cm}$ to greater than $20 \mathrm{~m}$; some of them are precariously balanced on the slopes (Brune, 1996) and constitute a serious hazard to the roads below. Eventually, cracks related to karst processes, and microforms related to limestone solution, were also observed.

The outer portions of the ridge were characterized by a system of release joints, whose trending mostly follows the edges of the ridge: in these cases, joints are open to loose, and a large number of the sites that are considered more likely to fail correspond to blocks delimited by such system. Release joints, decompression effects, and stress relief are a common feature in many mountain areas of the world (Mencl, 1974; Bovis and Evans, 1995).

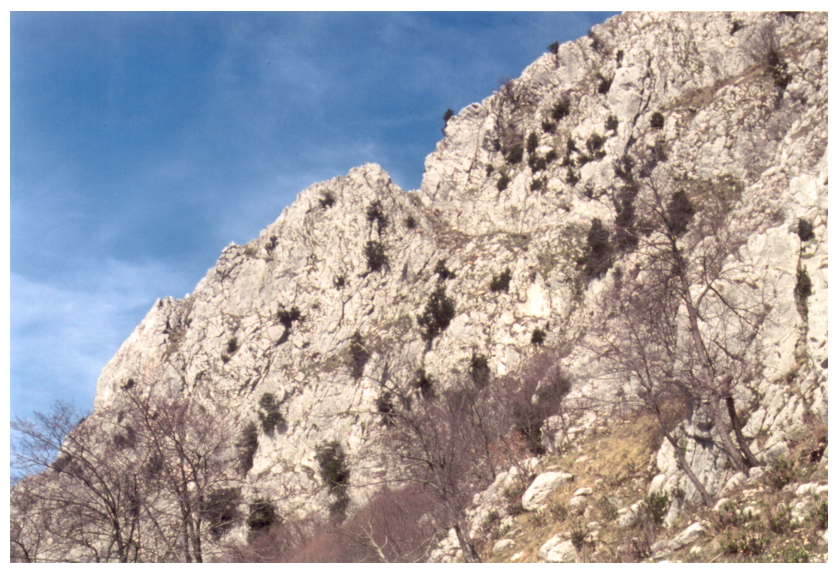

Fig. 7. View of the western slope of Mt. Marzano: the two main discontinuity systems that are present in this portion of the mountain make likely detachment as wedge failures in the carbonate rocks.

Most of the type of failures observed at the headscarps of known rock falls were of the sliding-type (Fig. 7). Sliding is actually limited to the first translational stage of failure along the rock surface, while subsequent development of rock fall commonly occurs through air free fall, impact on the underlying talus slope, and bouncing or rolling, or a combination of the two processes. Much more limited are topple failures, generally related to the above described release joint systems. The combined effect of many factors, such as block size, rock-joint strength, geometry and orientation of blocks with regard to the slope, seismic shaking, precipitation, freezethaw activity, etc., makes very hard the specific prediction of the headscarps which are most likely to fail. Nevertheless, overhanging blocks, likely warning of future failures, were observed at many sites.

\subsection{Seismic rock-fall susceptibility}

It may happen that, prior to some seismically-induced rock fall, a given site appeared to have had only a minimal rockfall hazard potential. However, the unpredictability of the rock-fall path always has to be considered, as many unexpected episodes of rock falls have repeatedly demonstrated (e.g. Zellmer, 1987). Even though rock-fall events occur every year, according to reports by local inhabitants, it is certain that moderate to strong earthquakes in Irpinia and nearby seismogenetic regions are able to trigger a much higher number of rock falls, and other types of landslide as well (Parise, 2000). For this reason, two recently proposed empirical methods, which are based on a collection of characteristics and properties of slopes, and of fractures and joints in the rocks, have been implemented in order to evaluate the seismic susceptibility to rock falls along the Mt. Valva - Mt. Marzano ridge. These methods represent the methodology proposed by Keefer (1993), and that proposed by Harp and Noble (1993).

The method by Keefer uses data from existing maps, reports, aerial photographs, and reconnaissance-level field ob- 
servations, to assess the seismic stability of rock slopes at a regional scale. It is based on observed associations between landslide concentrations (number of landslides per square kilometer) and slope characteristics in 24 earthquakes that occurred in various parts of the world. Eight slope characteristics (steepness, local relief, weathering, induration, open fissures, closely spaced fissures, vegetation, water) are organized into a dichotomous decision tree, which is also supplemented by additional criteria for pre-existing landslide deposits, engineered slopes, and potential rock-avalanche sources. As Keefer himself stated, the level of detail in the assessment of seismic rock-slope stability depends primarily on the level of detail in the available input data and secondarily on such other conditions as the heterogeneity of the slope materials being evaluated (Keefer, 1993). In this case study, most of the examined ridge resulted from having high seismic susceptibility to rock falls, which becomes very high at the edges of the rock cliffs. Low susceptibility was determined at a few sites where local fracturing in the rock mass appeared to be less pervasive.

Harp and Noble (1993) devised an engineering criteria for evaluating the seismic susceptibility of slopes to rock falls that uses the characteristics of rock discontinuities (fractures, joints, bedding) to quantify its potential for failure under seismic conditions. The method is based on the modification of an engineering classification which was originally used in tunnel design (rock mass quality designation, $\mathrm{Q}$, by Barton et al., 1974). It is an empirical method which was first implemented by analyzing the landslides triggered by the 25-27 May 1980 earthquake sequence of Mammoth Lakes, California (Harp et al., 1984). Harp and Noble (1993) calculate the "rock mass quality" through analysis and description of six factors which depend directly or indirectly on the fracture properties of a rock mass. These are: $J_{v}$, total number of joints per cubic meter; $J_{n}$, number of joint sets in the rock mass; $J_{r}$, joint roughness number; $J_{a}$, joint alteration number; $J_{w}$, joint water reduction factor; $\mathrm{AF}$, aperture factor. These six factors are evaluated by comparing the discontinuities in the rock mass with descriptive tables. The value of $Q$ at each survey station is given by the following equation:

$Q=\left[\frac{(115-3.3) J_{v}}{J_{n}}\right]\left[\frac{J_{r}}{J_{a}}\right]\left[\frac{1}{A F}\right]$.

It has to be stressed that the authors assume the joint water reduction factor, $J_{w}$, to be equal to unity; they state that "...for the purposes of evaluating seismic stability of slopes at the surface, this generally is not a significant factor because most rock slopes are dry ..." (Harp and Noble, 1993). Values of $Q$ lower than 1.00 would indicate a high degree of susceptibility, while moderate susceptibilities are comprised within the range 1.00-9.9, and low susceptibilities are indicated by values of $Q$ greater than 10.0 (Wieczorek and Harp, 2000). In the case of the Mt. Valva - Mt. Marzano ridge, $61 \%$ of the examined sites have $Q<1$, which attests to an overall high seismic susceptibility to rock falls; in many cases, susceptibility is very high, with $Q$ values down to 0.12 .
Table 2. Factors considered in the methods by Keefer (1993) and by Harp and Noble (1993) for evaluating the seismic rock-fall susceptibility

\begin{tabular}{lcc}
\hline & $\begin{array}{r}\text { Keefer } \\
(1993)\end{array}$ & $\begin{array}{c}\text { Harp and Noble } \\
(1993)\end{array}$ \\
\hline Slope characteristics & $\mathrm{x}$ & \\
Vegetation & $\mathrm{x}$ & \\
Water & $\mathrm{x}$ & \\
Rock weathering & $\mathrm{x}$ & $\mathrm{x}$ \\
Rock strength & $\mathrm{x}$ & \\
Frequency of fractures & & $\mathrm{x}$ \\
Spacing of fractures & $\mathrm{x}$ & $\mathrm{x}$ \\
Aperture of fractures & $\mathrm{x}$ & $\mathrm{x}$ \\
Infilling material & & $\mathrm{x}$ \\
Roughness & & $\mathrm{x}$ \\
\hline
\end{tabular}

Comparing the results obtained from the two methodologies, it has to be noted that Keefer's method appears to be much more rapid, but it is based on a smaller amount of field data and analysis. It allows one to perform in a relatively short time a preliminary evaluation of the seismic susceptibility, and has its most suitable application at regional rather than local scale, and particularly in establishing priorities for conducting site-specific slope stability evaluation and analysis. Harp and Noble's method, on the other hand, relies on a more detailed and local geostructural survey of the rock mass, which permits one to have very good information for zonation of the slopes. However, some factors, such as slope relief and vegetation, are not considered in the method (cf. Table 2), and the role of water is underestimated; the latter, in particular, might result in an overestimation of slope stability. Even with the above delineated differences, it has to be stressed that distribution and seismic susceptibility to rock falls along the Mt. Valva - Mt. Marzano ridge, obtained from the two methods, is quite similar. Two sectors with very high susceptibility were identified: the western slopes of Mt. Valva, and the rock cliffs above the town of Valva. High susceptibility also characterizes large sectors of the southern area, in particular, the Mt. Marzano southern slope and the rocky spur above the town of Colliano. Eventually, seismic susceptibility to rock falls appears to be moderate to locally low in the middle-lower portion of the rock cliffs.

\section{Zonation}

Following the definition by Varnes (1984), a zonation concerning slope movements is intended as a division of the land surface into areas, and the ranking of these areas according to degrees of actual or potential hazard from landslides on slopes. Zonation from scientific studies does not generally imply legal restrictions, but can be useful to those people who directly manage the territory, providing them with indispensable information for planning purposes. 
Table 3. Main constraints used for zonation

\begin{tabular}{cl}
\hline Source area & $\cdot$ occurrence of previous rock failures \\
& $\cdot$ steep topography \\
& $\cdot$ fractured rock mass \\
& $\cdot$ high altitude \\
& $\cdot$ high relief \\
& $\cdot$ high to very high seismic rock-fall susceptibility \\
\hline Talus slope & $\cdot$ deposits related to past slope instability \\
& $\cdot$ high slope gradient \\
\hline Rock-fall shadow & $\cdot$ vegetation absent or scarce \\
& $\cdot$ presence of scattered or isolated boulders \\
& $\cdot$ direct witnesses \\
\hline Safe area & $\cdot$ absence of boulders or rock debris \\
& $\cdot$ medium to low slope gradient
\end{tabular}

The use of geological evidence to ascertain the past behaviour of a rock slope over a long period has been suggested by several authors (e.g. Evans and Hungr, 1993); extrapolation of this information could then be used to predict the reach of future rock falls within a given return period. Landslide hazard zonation of slopes has to rely on historical and geological data. In the present case study, an attempt to combine information derived from the two approaches was made; due to high seismicity of the area, and to the importance of earthquakes as triggering factors, a particular stress was given to the geostructural analysis of the slopes, aimed at evaluating the seismic susceptibility to rock falls. A zonation of the Mt. Valva - Mt. Marzano ridge was performed (Fig. 8) by subdividing the slopes into four areas, based on processes that take place in the different sectors, and following the constraints summarized in Table 3. The four areas are described as follows: 1) the source area; 2) the talus slope; 3) the rock-fall shadow; 4) the safe area.

The source area corresponds to sites where recent activity attests to the occurrence of rock falls or toppling failures, and future detachment of rocks is more likely. This area extends along the entire upper slopes, where steeply inclined to vertical rock walls are present; it includes all of the known detachment areas of previous rock falls. The main constraints used for identification of the source area (Table 3) were, in addition to those mentioned before, a high degree of fracturing in the rock mass, high altitude (which favours freeze and thawing process in joints and fractures), and the recognition of high to very high seismic susceptibility to rock falls, evaluated through the methods described in the previous section. Upper limits of the source area correspond to changes in topography, with the passage to smooth erosional surfaces at the top of the examined ridge. A further area which has been zoned as a source area of rock falls is the rocky spur where Collianello lies, and just below is the town of Colliano. From this sector, rock falls were triggered during the 1980 earthquake (Budetta, 1983; Carrara et al., 1986); future rock falls could occur at this site, which determines very high rock-fall vulnerability, due to the location of the houses immediately at the base of the rock cliff.

In the zonation of the rock-fall source area, the information obtained through Keefer's and Harp and Noble's methods were incorporated: as shown in Table 3, high to very high seismic rock-fall susceptibility is, in fact, regarded as one of the constraints that has to be taken into account for delimiting the rock-fall source areas. In particular, given that (as discussed in the previous section) the method by Harp and Noble had greater suitability for evaluating the seismic rock-fall susceptibility at a local scale, the sites showing the highest values of susceptibility according to this method are also shown in Fig. 8. It has to be noted, however, that most of these sites were also ranked as having very high or extremely high rock-fall susceptibility in the Keefer's method.

Once detached from a source area, the rocks could stop at the immediate base of the rock walls, or, as is the common case, move by bouncing, rolling or a combination of the two processes, on the second identified zone, which is the talus slope. This is of particular importance, since the slope gradient controls the evolution of the movement; in other words, it can work as a ramp for the fallen blocks, allowing them to reach the down-valley sectors. Another feature to be considered is the presence of vegetation, since trees and bushes might have a protective action against falling rocks, and cause them to slow down, or to stop. As mentioned before, vegetation is either very scarce or absent in the Mt. Valva and Mt. Marzano slopes; this, combined with the very limited presence of retaining walls and other protective structures, again determines high vulnerability for the anthropogenic structures at the mountain foothills. A similar conclusion derives from the absence of topographic ledges on the talus slope, where fallen rocks could release their energy and stop.

The third sector of the zonation is probably the most difficult to ascertain, since it is related to the maximum travel distance of blocks detached from the rock cliffs. Many studies in the last decades have been devoted to such a topic: as an 


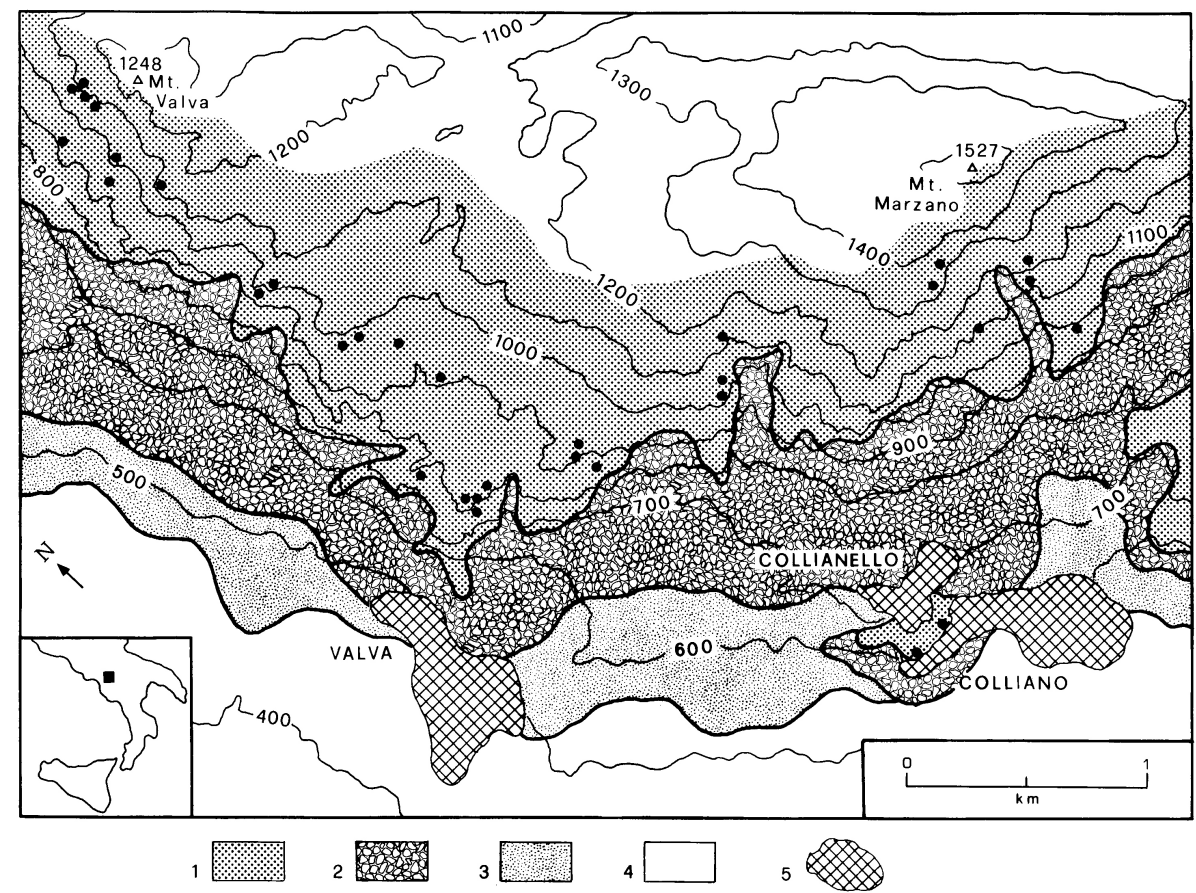

Fig. 8. Zonation map of the Mt. ValvaMt. Marzano ridge. Explanation: 1) rock-fall source area; 2) talus slope; 3) rock-fall shadow; 4) safe area; 5) town. The sites showing the highest values of susceptibility according to the method by Harp and Noble (1993) are shown as black dots. example, the runout distance of rock falls at the base of talus slopes was estimated by Onofri and Candian (1979), who analyzed about 100 rock falls triggered by the 1976 Friuli earthquake in north eastern Italy. They suggested the use of a rock-fall fahrböschung $(\beta)$, that is the angle of inclination of the course along which a rockfall raced (Hsü, 1975). Limit values for $\beta$ were 28 and $41^{\circ}$ (Onofri and Candian, 1979); use of rock-fall fahrböschung requires one, by necessity, to measure starting and end points for any individual rock fall. The minimum shadow angle (i.e. the angle between the lines defined, respectively, by the highest point of the rock-fall source area and the apex of the talus slope, and by the latter and the distal point of the rock-fall shadow) was proposed, on the other hand, by Evans and Hungr (1993): they suggested that the use of an empirical minimum shadow angle of $27.5^{\circ}$ would appear to be a useful method for the preliminary estimation of the maximum rock-fall reach. Runout distance of rock fall, and the effect on it of the involved volume of rocks, has also been recently studied by means of outdoor rock-fall experiments and simulations that have shown the existence of a positive correlation between runout distance and rock-fall volume (Okura et al., 2000).

In the zonation proposed here, the concept of rock-fall shadow has been considered: it is defined as "that part of the substrate surface covered discontinuously by scattered large boulders that have rolled or bounced beyond the base of the talus" (Hungr and Evans, 1988; Evans and Hungr, 1993). Scattered boulders lying beyond the talus are also described by other authors as "outliers" (Wieczorek et al., 1999). Definition of the rock-fall shadow is very important, because here awareness of the hazard is much less obvious than in the previous zone; it might, therefore, represent the most dangerous sector, also due to the presence of settlements and infrastructures. The main problem in zonation of the rock-fall shadow is the knowledge of the maximum travel distance of fallen blocks, information that is not very easy to obtain, especially in areas (as the case shown here) where inhabited areas are located close to the mountains. Clearing of fallen material tends to cancel quickly any evidence of past slope movements, and frequently, the only source of information is represented by the accounts (whose reliability is highly variable) from local inhabitants. In the few cases when observations of old fallen blocks at the foothills of the study area, and their attribution to a specific rock-fall source area, were possible, shadow angles in the range between 31 and $38^{\circ}$ have been determined.

It has to be stressed again that, due to high velocity of the moving material, the types of landslide dealt with here can be extremely dangerous even when involving small volumes of rock material. Particular focus must, therefore, be made on the maximum travel distance of fallen blocks; this could be investigated, for example, through detailed measurements of the morphometric characteristics of the rock cliffs and the underlying slopes aimed at performing statistical analysis of the more likely runout distance of rock falls, or at simulating rock fall trajectories by means of mechanical methods and associated computer codes (e.g. Descoeudres and Zimmermann, 1987; Hoek, 1998).

Eventually, the safe area is the lowermost sector of the zonation presented here (Fig. 8): it is that portion of the slope that is beyond the reach of fallen blocks. The safe area generally corresponds to a decrease in the slope gradient, toward medium to low values. It must be stressed that a different level of certainty (in the sense of Wieczorek, 1984) is present 
in the limits of the various zones. The first two (source area and talus slope) were defined with good to high certainty, based mostly on detailed field work, and aerial photo interpretation, supported by the available historical data. A much lower degree of certainty is present in the limits of the rockfall shadow, and consequently of the safe area, since removal of the rocky and debris material made it difficult to determine a precise understanding of the maximum travel distance of the fallen blocks. Due to these difficulties, the boundary between rock-fall shadow and the safe area had to be based mostly on a historical investigation and interviews with local inhabitants, even though susceptibility in the above source areas was also taken into account; this makes it much less certain than the other boundaries drawn on the basis of geological and geomorphological investigations. A better estimate of the upper limit of the safe area could be performed through implementation of some of the available computerbased programs for forecasting the maximum reach of fallen blocks. Even with the above limitations, however, the zonation presented here is considered valid for a preliminary analysis of the rock-fall hazard in areas where there is either low or no awareness of such hazard.

\section{Discussion}

After the last catastrophic landsliding and flooding events which have occurred in the Italian territory in the few last years (1996 flood in Versilia, Tuscany; 1998 mud and debris flows at Mount Pizzo d'Alvano, Campania; 2000 flood at Soverato, Calabria), a strong need toward better knowledge of the areas potentially affected by landslides and floods has been developing in the scientific, as well as in the administrative communities. Nevertheless, there still exists too many sites in Italy where a lack of awareness of the landslide problem determines high vulnerability and risk for manmade structures. Concerning rock falls, it has to be noted that due to the increasing human activity in mountainous areas worldwide, there is the need to recognize the zones that are potentially affected by these slope movements and to exclude them from planning resource development, or to design the most suitable and feasible protection structures. To correctly assess the hazard related to a certain type of slope movement, and to calculate quantitative risk analysis (Peckover and Kerr, 1977; Astè et al., 1984; Fell, 1994), the magnitude and frequency of landslides have to be known (Gardner, 1983; Whitehouse and Griffiths, 1983). In the case of rock falls, magnitude is represented by the volume of involved rocks, while frequency is the number of events (regardless of their size) occurring in a given time span. Some valuable efforts have been recently aimed at dating past rock-fall events by means of methods such as lichenometry (Bull et al., 1994; Bull and Brandon, 1998). However, unavailability or incompleteness of extensive historic records about rock falls is still a serious problem in many mountain areas, especially those where settling has occurred over the last few decades.

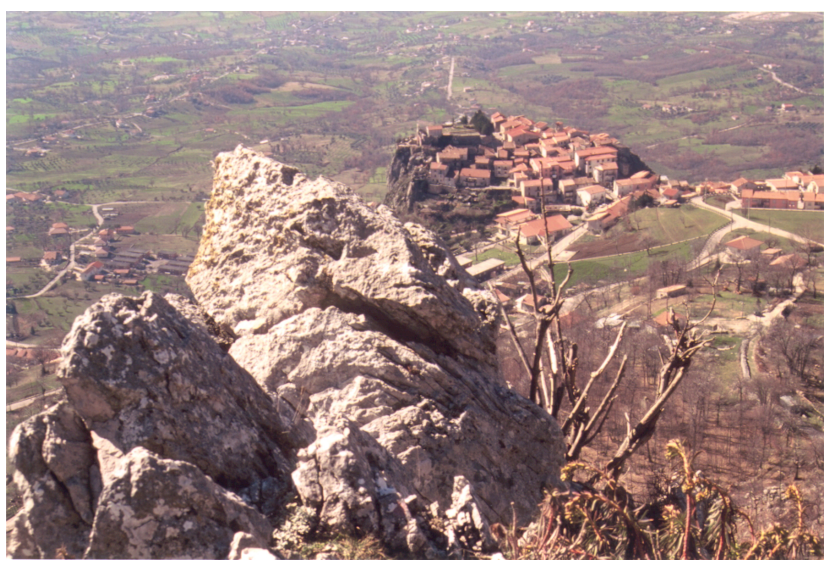

Fig. 9. View of the town of Collianello from the Mt. Marzano southwestern slope. In the foreground, highly fractured limestones, with open or loose joints in the rock mass.

Along transportation corridors running through mountainous areas, rock-fall activity should be documented by inspections of maintenance personnel. Even when such documentation is available, however, it presents many limitations (Bunce et al., 1997): small-sized rock falls are generally not recorded, unless they cause damage to vehicles and people; in addition, the source area of rock fall, which is a very important feature to be considered in the evaluation of the rockfall hazard, can hardly be recognized by untrained people. A further significant limitation is the removal of fallen rock from highways and roads, without any record being made. All these limitations, and still others, cause incompleteness in the documented rock-fall activity (Wieczorek and Jäger, 1996; Hungr et al., 1999), which, on the other hand, is in most of the cases limited to a time span ranging from some years to a few decades. A low number of recorded data represents the main drawback in statistical analysis of rock falls.

Mitigation of the risk related to rock falls and topple failures cannot be achieved without reaching an awareness of the hazard by local authorities and a full perception of the problem by citizens (Brown and Kockelman, 1983; Alexander, 1992). Transferring scientific information to non-technicians and administrators is not, on the other hand, a simple matter: much effort has to be made in order to keep maps and accompanying reports as simple as possible, at the same time without losing the scientific basis on which they are based. Simplicity of the maps, and ready comprehension of their content by those people charged with the management of the territory (administrators, politicians, land use planners) are, therefore, mandatory steps in the mitigation of the risk related to slope movements, and one of the first actions in the strategy for reducing the landslide hazard (Kockelman, 1986).

The zonation presented in this paper represents an attempt in this direction: even kept simple for the reasons delineated above, it could represent a useful tool toward: a) providing the preliminary information to anybody involved in land management and control, particularly useful in areas (such as the case study presented here) where no specific map about 
rock-fall activity is available and awareness of the rock-fall hazard is very subtle; b) a better understanding of the rockfall hazard by people who are still unaware of it; c) a preliminary division of the land surface into zones that might help in identifying those areas most likely to be involved by the arrival of fallen material. In addition, it could also help in assessing vulnerability and risk of settlements (Fig. 9), roads, and other infrastructures; this latter step should be correctly performed through an interdisciplinary approach, with the contribution, in addition to geologists and engineering geologists, of other professionals dealing with social and economical sciences, and land use planning.

The different methods (field survey, aerial photo interpretation, historical investigation, interviews with inhabitants, etc.) that were used to obtain the zonation described in this paper had variable relative importance in mapping the four areas: direct geological and geomorphological surveys, integrated by aerial photo interpretation, were more reliable, and thus played a preeminent role in the definition of the zonation boundaries.

Acknowledgements. I am grateful to P. Reichenbach (CNR-IRPI, Perugia) and to the two anonymous referees for the valuable comments and suggestions made on the first version of the manuscript.

\section{References}

Abele, G.: Kinematik und Morphologie spät und postglazialer Bergstürze in den Alpen, Zeit. für Geomorph., suppl. 14, 138149, 1972.

Alexander, D.: On the causes of landslides: human activities, perception, and natural processes, Environ. Geol. Water Sci., 20, 3, 165-179, 1992.

Amato, A., Cinque, A., Santangelo, N., and Santo, A.: Il bordo meridionale del Monte Marzano e la valle del F. Bianco: geologia e geomorfologia, Studi Geol. Camerti, vol. spec. 1992/1, 191200, 1992

Astè, J. P., Cambou, B., and Falcetta, J. L.: Comportement des masses rocheuse instables. De la prevision a la prevention, Proc. 4th Int. Symp. on Landslides, Toronto (Canada), 1, 441-446, 1984.

Barrows, A. G.: Rockfalls and surface effects other than faulting (Landers and Big Bear earthquakes), California Geology, January/February 1993, 17-22, 1993.

Barton, N., Lien, R., and Lunde, J.: Engineering classification of rock masses for the design of tunnel support, Norw. Geotechn. Inst., Oslo (Norway), 1974.

Boschi, E., Guidoboni, E., Ferrari, G., Mariotti, D., Valensise, G., and Gasperini, P., (Eds.): Catalogue of strong Italian earthquakes from 461 B.C. to 1997, Annali di Geofisica, 43, 4, 609-868, with CD-ROM, 2000.

Bovis, M. J. and Evans, S. G.: Rock slope movements along the Mount Currie "fault scarp", southern Coast Mountains, British Columbia, Can. J. Earth Sc., 32, 2015-2020, 1995.

Brancaccio, L., Cinque, A., Romano, P., Rosskopf, C., Russo, F., Santangelo, N., and Santo, A.: Geomorphology and neotectonic evolution of a sector of the Tyrrhenian flank of the southern Apennines (Region of Naples, Italy), Zeit. für Geomorph. N. F., suppl. 82, 47-58, 1991.
Brown, R. D. jr. and Kockelman, W. J.: Geologic principles for prudent land use, U.S. Geol. Surv. Prof. Paper 946, 97, 1983.

Broili, L.: Relations between scree slope morphometry and dynamics of accumulation processes, in "Rockfall dynamics and protective works effectiveness”, ISMES, Bergamo (Italy), 90, 11-24, 1977.

Brune, J. N.: Precariously balanced rocks and ground-motion maps for southern California, Bull. Seism. Soc. Am., 86, 43-54, 1996.

Budetta, P., Geologia e frane dell'alta valle del F. Sele (Appennino Meridionale), Mem. Note Ist. Geol. Appl., Napoli (Italy), 16, 53, 1983.

Budetta, P. and Santo, A.: Morphostructural evolution and related kinematics of rockfalls in Campania (southern Italy): a case study, Eng. Geol., 36, 197-210, 1994.

Bull, W. B. and Brandon, M. T.: Lichen dating of earthquakegenerated regional rockfall events, Southern Alps, New Zealand, Geol. Soc. Am. Bull., 110, 1, 60-84, 1998.

Bull, W. B., King, J., Kong, F., Moutoux, F., and Phillips, W. M.: Lichen dating of coseismic landslide hazards in alpine mountains, Geomorphology, 10, 253-264, 1994.

Bunce, C. M., Cruden, D. M., and Morgenstern, N. R.: Assessment of the hazard from rock fall on a highway, Can. Geotech. J., 34, 344-356, 1997.

Caine, N.: Toppling failures from Alpine cliffs on Ben Lomond, Tasmania, Earth Surf. Proc. and Landf., 7, 133-152, 1982.

Carrara, A., Agnesi, V., Macaluso, T., Monteleone, S., and Pipitone, G.: Slope movements induced by the Southern Italy earthquake of November 1980, Geol. Appl. e Idrogeol., 21, 2, 237250, 1986.

Cinque, A., Patacca, E., Scandone, P., and Tozzi, M.: Quaternary kinematic evolution of the Southern Apennines. Relationships between surface geological features and deep lithospheric structures, Annali di Geofisica, 36, 2, 249-260, 1993.

Coppola, L., and Pescatore, T., Lineamenti di neotettonica dei Monti Terminio-Tuoro, Cervialto e Marzano (Appennino Meridionale), Boll. Soc. Geol. It., 108, 105-119, 1989.

Cruden, D. M. and Varnes, D. J.: Landslide types and processes, in Turner, A. K. and Schuster, R. L., (Eds.), Landslides. Investigation and mitigation, Transp. Res. Board, Nat. Res. Council, Spec. Rep. 247, Washington, D.C., 36-75, 1996.

Dade, W. B. and Huppert, H. E.: Long-runout rockfalls, Geology, 26, 9, 803-806, 1998.

Dearman, W. R.: Engineering properties of carbonate rocks, Bull. Int. Ass. Eng. Geol., 24, 3-17, 1981.

de Freitas, M. H. and Watters, R. J.: Some field examples of toppling failure, Geotechnique, 23, 4, 495-514, 1973.

de Riso, R.: Sulla geologia e lo stato di dissesto idrogeologico dell'alta valle del Fiume Sele (Campania), Mem. e Note Ist. Geol. Appl., Napoli (Italy), 10, 43, 1967.

Dershowitz, W. S. and Einstein, H. H.: Characterizing rock joint geometry with joint system models, Rock Mech. Rock Eng., 21, 1, 21-51, 1988.

Descoeudres, F. and Zimmermann, T.: Three-dimensional dynamic calculation of rockfalls, Proc. 6th ISRM Congress, 1, 337-342, 1987.

Eisbacher, G. H.: Cliff collapse and rock avalanches (Sturzstroms) in the Mackenzie Mountains, north western Canada, Can. Geotech. J., 16, 309-334, 1979.

Eisbacher, G. H. and Clague, J. J.: Destructive mass movements in high mountains: hazard and management, Geol. Surv. Canada paper 84-16, 230, 1984.

Erismann, T. H. and Abele, G.: Dynamics of rockslides and rock- 
falls, Springer Verlag, 316, 2001.

Esposito, E., Porfido, S., Simonelli, A. L., Mastrolorenzo, G., and Iaccarino, G.: Landslides and other surface effects induced by the 1997 Umbria-Marche seismic sequence, Eng. Geol., 58, 353376, 2000.

Evans, S. G. and Hungr, O.: The assessment of rockfall hazard at the base of talus slopes, Can. Geotech. J., 30, 620-636, 1993.

Fell, R.: Landslide risk assessment and acceptable risk, Can. Geotech. J., 31, 261-272, 1994.

Flageollet, J. C. and Weber, D.: Fall, in Dikau, R., Brunsden, D., Schrott, L., and Ibsen, M. L. (Eds.), Landslide recognition, John Wiley and Sons Ltd., 13-28, 1996.

Fookes, P. G. and Hawkins, A. B.: Limestone weathering: its engineering significance and a proposed classification scheme, Quart. J. Eng. Geol., 21, 7-31, 1988.

Gardner, J.: Rockfall frequency and distribution in the Highwood Pass area, Canadian Rocky Mountains, Zeit. für Geomorph. N.F., 27, 3, 311-324, 1983.

Geological Society Engineering Group Working Party, The description of rock masses for engineering purposes, Quart. J. Eng. Geol., 10, 355-388, 1977.

Goguel J.: Scale-dependent rockslide mechanisms, in Voight, B., (Ed.), Rockslides and avalanches, 1. Natural phenomena, Devel. in Geotech. Eng., 14A, Elsevier, 693-705, 1978.

Hadley, J. B.: Landslides and related phenomena accompanying the Hebgen Lake earthquake of 17 August 1959, U.S. Geol. Surv. Prof. Paper 435, 107-138, 1964.

Harp, E. L. and Jibson, R. W.: Landslides triggered by the 1994 Northridge, California earthquake, Bull. Seism. Soc. Am., 86, 1, part B, S319-S332, 1996.

Harp, E. L. and Noble, M. A.: An engineering rock classification to evaluate seismic rock-fall susceptibility and its application to the Wasatch Front, Bull. Ass. Eng. Geologists, 30, 3, 293-319, 1993.

Harp, E. L. and Wilson, R. C.: Shaking intensity thresholds for rock falls and slides: evidence from 1987 Whittier Narrows and Superstition Hills earthquake strong-motion records, Bull. Seism. Soc. Am., 85, 6, 1739-1757, 1995.

Harp, E. L., Wilson, R. C., and Wieczorek, G. F.: Landslides from the 4 February 1976, Guatemala earthquake, U.S. Geol. Surv. Prof. Paper 1204-A, 35, 1981.

Harp, E. L., Tanaka, K., Sarmiento, J., and Keefer, D. K.: Landslides from the 25-27 May 1980, Mammoth Lakes, California, earthquake sequence, U.S. Geol. Surv. Misc. Invest. Map I-1612, 1:62,500 scale, 1984.

Heim, A.: Bergstürze und Menschenleben, Fretz und Wasmuth, Zürich, 218,1932. (English translation by Skermer, N., Landslides and human lives, BiTech Publishers, Vancouver, B.C., 1989).

Hoek, E.: Analysis of rockfall hazards, Rock Engineering, Course notes, Chapter 9, http://www.rockeng.utoronto. ca/hoekcorner.htm, 115-136, 1998.

Hoek, E. and Bray, J. W.: Rock slope engineering, The Institution of Mining and Metallurgy, London, 358, 1981.

Howard, K. A.: Avalanche mode of motion: implications from Lunar examples, Science, 180, 1052-1055, 1973

Hsü, K. J.: Catastrophic debris streams (Sturzstroms) generated by rockfalls, Geol. Soc. Am. Bull., 86, 129-140, 1975.

Hudson, J. A. and Priest, S. D.: Discontinuity frequency in rock masses, Int. J. Rock Mech. Min. Sci., 20, 2, 73-90, 1983.

Hungr, O. and Evans, S. G.: Engineering evaluation of fragmental rockfall hazards, Proc. 5th Int. Symp. on Landslides, Lausanne
(Switzerland), 1, 685-690, 1988.

Hungr, O., Evans, S. G., and Hazzard, J.: Magnitude and frequency of rock falls and rock slides along the main transportation corridors of southwestern British Columbia, Can. Geotech. J., 36, 2, 224-238, 1999.

Ippolito, F., D'Argenio, B., Pescatore, T., and Scandone, P.: Structural-stratigraphic units and tectonic framework of Southern Apennines, in Squyres, C., (Ed.), Geology of Italy, Earth Science Soc. Libyan Arabic Republic, 317-328, 1975.

Keefer, D. K.: Landslides caused by earthquakes, Geol. Soc. Am. Bull., 95, 406-421, 1984.

Keefer, D.K.: The susceptibility of rock slopes to earthquakeinduced failure, Bull. Ass Eng. Geologists, 30, 3, 353-361, 1993.

Keefer, D. K.: Statistical analysis of an earthquake-induced landslide distribution - the 1989 Loma Prieta, California event, Eng. Geol., 58, 231-249, 2000.

Kent, P. E.: The transport mechanism in catastrophic rock falls, Journal of Geology, 74, 79-83, 1966.

Kockelman, W. J.: Some techniques for reducing landslide hazards, Bull. Ass. Eng. Geologists, 23, 1, 29-52, 1986.

Kotarba, A. and Stromquist, L.: Transport, sorting and deposition processes of alpine debris slope deposits in the Polish Tatra Mountains, Geografiska Annaler, 66A, 285-294, 1984.

Kowalski, W. C.: Engineering geological aspects of different types of karst corrosion and fracture generation in karst masses, Bull. Int. Ass. Eng. Geol., 44, 35-46, 1991.

La Pointe, P. R. and Hudson, J. A.: Characterization and interpretation of rock mass joint patterns, Geol. Soc. Am. Spec. Paper 199, 37, 1985.

Luckman, B. H.: Rockfalls and rockfall inventory data: some observations from Surprise Valley, Jasper National Park, Canada, Earth Surf. Proc., 1, 287-298, 1976.

Matznetter, K.: Der Vorgang der Massenbewegungen an Beispielen des Klostertales in Vorarlberg, Geogr. Jahresber. Öst., 25, 108, 1956.

McCalpin, J. P. and Nelson, A. R.: Introduction to paleoseismology, in McCalpin, J. P. (Ed.), Paleoseismology, Academic Press, San Diego, CA, 1-32, 1996.

Melosh, H. J.: Acoustic fluidization: a new geological process?, J. Geophys. Res., 84, 7513-7520, 1979.

Melosh, H. J.: The mechanics of large rock avalanches, in Costa J. E., and Wieczorek, G. F., (Eds.), Debris flows/avalanches: process, recognition, and mitigation, Geol. Soc. Am. Reviews in Eng. Geol., 7, 41-49, 1987.

Mencl, V.: Engineering-geological importance and possible origin of the stress relief of the rocks of the Cordillera Blanca, Peru, Bull. Int. Ass. Eng. Geol., 9, 69-74, 1974.

Moriwaki, H.: Geomorphological prediction of the travel distance of a debris, Proc. China - Japan Field Workshop on Landslides, Xian-Lanzhou (China), 79-84, 1987.

Morrissey, M. M., Savage, W. Z., and Wieczorek, G. F.: Air blasts generated by rockfall impacts: analysis of the 1996 Happy Isles event in Yosemite National Park, J. Geophys. Res., 104 (B10), 23189-23198, 1999.

Okura, Y., Kitahara, H., Sammori, T., and Kawanami, A.: The effects of rockfall volume on runout distance, Eng. Geol., 58, 109$124,2000$.

Onofri, R. and Candian, C.: Indagine sui limiti di massima invasione dei blocchi rocciosi franati durante il sisma del Friuli del 1976. Considerazioni sulle opere di difesa, Regione Autonoma Friuli-Venezia Giulia, 42, 1979.

Parise, M.: Evaluating rockfall hazard from carbonate slopes in the 
Sele Valley, Southern Italy, Proc. Int. Symp. "Slope stability engineering”, Matsuyama (Japan), 2, 1337-1342, 1999.

Parise, M.: Erosion rates from seismically-induced landslides in Irpinia, southern Italy, Proc. 8th Int. Symp. on Landslides, Cardiff (Wales), 3, 1159-1164, 2000.

Parise, M.: Landslide mapping techniques and their use in the assessment of the landslide hazard, J. Physics and Chem. of the Earth, part C, 26/9, 697-703, 2001.

Peckover, F. L. and Kerr, J. W. G.: Treatment and maintenance of rock slopes on transportation routes, Can. Geotech. J., 14, 487507, 1977.

Porter, S. C. and Orombelli, G.: Alpine rockfall hazards, Am. Scientist, 69, 67-75, 1981.

Shreve, R. L.: The Blackhawk landslide, Geol. Soc. Am. Spec. Paper 108, 47, 1968.

Tazieff, H.: Interprétation des glissements de terrain accompagnant le grand séisme du Chili, Bull. Soc. Belge de Géol., 69, 3, 1-11, 1961.

Terzaghi, R. D.: Sources of error in joint surveys, Geotechnique, 15, 287-304, 1965.

Varnes, D. J.: Landslide hazard zonation: a review of principles and practice, Unesco, Paris, 63, 1984.

Voight, B., (Ed.): Rockslides and avalanches, 1. Natural phenomena, Devel. in Geotech. Eng., 14A, Elsevier, 833, 1978.

Voight, B., Janda, R., Glicken, H., and Douglass, P. M.: Nature and mechanics of the Mount St. Helens rockslide-avalanche of 18
May 1980, Geotechnique, 33, 243-273, 1983.

Whalley, W. B.: Rockfalls, in Brunsden, D., and Prior, D. B., (Eds.), Slope instability, John Wiley and Sons Ltd., 217-256, 1984.

Whitehouse, I. E. and Griffiths: Frequency and hazard of large rock avalanches in the Central Southern Alps, New Zealand, Geology, 11, 331-334, 1983.

Wieczorek, G. F.: Preparing a detailed landslide-inventory map for hazard evaluation and reduction, Bull. Ass. Eng. Geologists, 21, 3, 337-342, 1984

Wieczorek, G. F. and Harp, E. L.: Rock-fall hazard assessment of the Aspen Forest trail, Navajo National Monument, Arizona, U.S. Geol. Surv. Open-File Rep. 00-305, 11, 2000.

Wieczorek, G. F. and Jäger, S.: Triggering mechanisms and depositional rates of postglacial slope-movement processes in the Yosemite Valley, California, Geomorphology, 15, 17-31, 1996.

Wieczorek, G. F., Morrissey, M. M., Iovine, G., and Godt, J.: Rockfall potential in the Yosemite Valley, California, U.S. Geol. Surv. Open-File Rep. 99-578, 1999.

Wieczorek, G. F., Snyder, J. B., Waitt, R. B., Morrissey, M. M. Uhrhammer, R., Harp, E. L., Norris, R. D., Bursik, M. I., and Finewood, L. 'G.: The unusual air blast and dense sandy cloud triggered by the 10 July 1996, rock fall at Happy Isles, Yosemite National Park, California, Geol. Soc. Am. Bull., 112, 1, 75-85, 2000.

Zellmer, J. T.: The unexpected rockfall hazard, Bull. Ass. Eng. Geologists, 24, 2, 281-283, 1987. 